\title{
OPTIMIUM INTER-ROW SPACING AND NUMBER OF PLOUGHINGS FOR TWO PROMISING SUGARCANE VARIETES
}

\author{
AHMED, Z.A., A.M. AHMED AND M.S.H. OSMAN
}

Sugar Crops Res. Inst., ARC, Giza, Egypt

(Manuscript received 3 November 2010)

\begin{abstract}
The present work was conducted at El-Mattana Agricultural Research Station, Luxor Governorate during 2008/2009 and 2009/2010 seasons to assess the optimum inter-row spacing and number of ploughings for two promising varieties. The study included twelve treatments, which were the combinations among three enter-row spacing $(80,100$ and $120 \mathrm{~cm}$ ) and two ploughing treatments (two or three passes) for the two promising sugar cane varieties namely G.95-19 and G.95-21. Split-split plot design with four replications was used in both seasons.

The obtained results showed that the examined enter-row spacing significantly affected the number of millable canes/fed, millable cane height and diameter, as well as total soluble solids, sucrose, sugar recovery percentages, cane and sugar yields/fed. The closest enter-row spacing $(80 \mathrm{~cm})$ gave the highest values of all studied traits. Moreover, insignificant difference was found between 80 and $100 \mathrm{~cm}$ inter-row spacing in the number of millable cane/fed, millable cane height, sucrose and sugar yield. Number of millable canes/fed, millable cane height, stalk diameter, total soluble solids and cane yield were significantly affected by ploughing number. Furthermore, practicing three ploughing passes resulted in the highest values of the aforementioned characters, except for stalk diameter. The promising sugarcane variety G.95-21 significantly surpassed G.95-19 the other promising one in number of millable canes/fed, millable stalk height, millable cane diameter, total soluble solids percentage and cane yield/fed.

Under conditions of the present investigation, planting G.9 5-21 sugarcane variety in rows spaced at $100 \mathrm{~cm}$ along with three ploughings can be recommended to obtain the highest cane and sugar yield/fed.
\end{abstract}

\section{INTRODUCTION}

It is known that soil preparation is the corner stone for higher production as well as the nutritional status to maximize productivity vertically. Row spacing has a direct influence on plant population. It plays a distinct role in the amount of solar radiation intercepted and hence, crop canopy development which in turn affects photosynthesis and ultimately the dry matter produced by plant. Also, it may affect cane diameter, length and weight which contribute to cane yield. Meantime, the appropriate seed bed preparation help in increasing size of root system, i.e. increases its proliferation vertically and horizontally, which guarantee better absorption of nutrients, basal tellering and decrease lodging, which positively yield higher cane and sugar per feddan. (kanwar, et al., 1988, El-Sayed, 2000, Shah-Nawaz, et al., 2000, Raskar and Bhoi, 2003, Osman, et al., 2004, Ahmed, et al., 2005, El-Shafai and Ismail, 2006 and Ahmed and Khaled, 2008). 
Many studies were carried out to evaluate sugarcane varieties for productivity and quality parameters under different agricultural treatments (Yadav and Sharma, 1980, Gowda, et al., 2001, El-Geddawy, et al., 2002, Sundara, 2003 and Taha, et al., 2008).

The main objective of the present work was to find out the optimum interrow space and number of ploughings for two promising sugarcane varieties which in order to achieve higher cane and sugar yields.

\section{MATERALS AND METHODS}

The present study was conducted at El-Mattana Agricultural Research Station, Luxor Governorate during 2008/2009 (plant cane crop) and 2009/2010 (first ratoon) seasons to assess the optimum inter-row spacing and number of ploughings for two promising varieties. The study included twelve treatments, which were the combinations among three inter-row spacing $(80,100$ and $120 \mathrm{~cm})$ and two ploughing treatments (two or three passes ) for the two promising sugar cane varieties namely G.95-19 and G.95-21, which were planted during the first week of March for the plant cane using two rows of three-budded cane cuttings in planting. However, management of the first ratoon crop started during the second week of March after harvesting the plant cane.

Split-split plot design with four replications was used in both seasons. Inter-row spacings were arranged in the main plots, while number of ploughings were randomly distributed in sub-plots, and the sub-sub plots were assigned for the examined sugarcane varieties. The sub-sub-plot area was $60 \mathrm{~m}^{2}$ (including 15, 12 and 10 rows in case of spacing 80,100 and $120 \mathrm{~cm}$ spacings, respectively and $5 \mathrm{~m}$ in length). All the agronomic practices for growing sugar cane were done as recommended by the Sugar Crops Research Institute. Mechanical and chemical analyses of soil of the experimental site showed that soil was clay loam, containing 30,9 and 205 ppm of the available N, P and $\mathrm{K}$, respectively and a $\mathrm{pH}$ of 7.5 .

\section{Recorded data:}

At harvest, the following characters were determined:

1. Number of millable cane per feddan (based on plot area).

2. Millable cane height $(\mathrm{cm})$ was measured from soil surface up to the top visible dewlap.

3. Millable cane diameter $(\mathrm{cm})$ was measured at the middle part of stalks. 
A sample of twenty millable stalkes from each split-split plot was randomly taken, cleaned and crushed to determine total soluble solids and sucrose percentages of juice as follows:

4. Total soluble solids (TSS \%) in juice (brix percentage) was determined using "Brix Hydrometer" according to A.O.A.C. (1995).

5. Sucrose percentage in juice was determined using "Saccharemeter" according to A.O.A.C. (1995).

6. Sugar recovery percentage in juice was calculated according to the equation described by Yadav and Sharma (1980):

Sugar recovery $\%=[$ sucrose $\%-0.4$ (brix \% - sucrose $\%)] \times 0.73$.

7. Cane yield (ton/fed) was calculated based on plot area.

8. Sugar yield (ton/fed) was estimated as follows:

Sugar yield $($ ton $/$ fed $)=$ cane yield $($ ton $/$ fed $) \times$ sugar recovery $\%$.

\section{Statistical analysis}

All recorded data were statistically analyzed according to the method of Snedecor and Cochran (1981). Least significant difference test (LSD) at $5 \%$ level of significance was used to compare means.

\section{RESULTS AND DISCUSSION}

\section{Number of millable cane stalks/fed:}

Data in Table 1 point out that number of millable cane was significantly and negatively influenced by increasing row spacing from 80 up to $120 \mathrm{~cm}$ in the $1^{\text {st }}$ and $2^{\text {nd }}$ seasons. This result could be due to indicated that shading and competition among plants at narrow spacing $(80 \mathrm{~cm})$ were very high and resulted in high mortality percentage, because among 63000 buds/fed planted, only 49.19 and 48.64 thousand millable cane stales/fed were harvested, in the $1^{\text {st }}$ and $2^{\text {nd }}$ season, respectively. Meanwhile, at the widest row distance $(120 \mathrm{~cm})$, planting 42000 buds/fed produced 45.80 and 44.54 thousand millable cane stales stalks /fed, probably due to lower competition and higher tillering ability resulted from the suitability of furrowing and earthing-up around plants. These results are in agreement with those mentioned by Shah-Nawaz, et al. (2000), Raskar and Bhoi (2003) and Sundara (2003) who found that planting canes in narrower rows of $75 \mathrm{~cm}$ produced the highest number of millable cane stalks.

Number of millable cane stalks/fed was significantly influenced by ploughing number in the two seasons. Carrying out three ploughing passes resulted in 0.97 and 1.07 thousand millable canes/fed higher than those produced by practicing two ploughing passes, in first and second season, respectively. These results are probably 
attributed to the fact that increasing ploughing number ensures favourable soil conditions for growth and an efficient function of root system, in addition to better aeration, availability of nutrients in the soil solution and basal tillering of stalks, and hence higher number of millable cane stalks /fed. Similar results were reported by ElSayed (2000) and Ahmed, et al. (2005).

Results given in the same table revealed that evaluated sugarcane cvs. differed significantly in the number of millable cane stalks / fed in second season only. Sugarcane cv. G. 95-21 produced 0.57 thousand millable canes/fed higher than those recorded by G. 95-19. This result may be due to the genetic difference between the two varieties in tillering ability and capacity of producing more survive and harvestable stalks. Significant differences among cane cvs. in this trait were also reported by Gowda, et al. (2001), El-Geddawy, et al. (2002), and Taha, et al. (2008) who obtained significant differences among different varieties.

It could be noted that the number of millable cane/fed significantly responded to all possible interactions in the two crops except the interaction between number of ploughing and sugarcane varieties in second season. In general, it was found that preparing seed bed by ploughing soil in two passes and planting G.95-21 sugarcane variety in rows spaced at $80 \mathrm{~cm}$ gave the highest number of millable cane stalks /fed.

Table 1. Number of millable cane stalks (1000/fed) of the tested sugarcane varieties as affected by row spacing and number of ploughing passes.

\begin{tabular}{|c|c|c|c|c|c|c|c|}
\hline \multirow{2}{*}{$\begin{array}{c}\text { Row } \\
\text { Spacing }\end{array}$} & \multirow{2}{*}{$\begin{array}{c}\text { Number of } \\
\text { Ploughing } \\
\text { passes }\end{array}$} & \multicolumn{3}{|c|}{ Plant cane crop } & \multicolumn{3}{|c|}{ First ratoon crop } \\
\hline & & $\begin{array}{c}\text { G. 95- } \\
19\end{array}$ & $\begin{array}{c}\text { G. } 95- \\
21\end{array}$ & Mean & $\begin{array}{c}\text { G. } 95- \\
19 \\
\end{array}$ & G.95-21 & Mean \\
\hline \multirow{2}{*}{$80 \mathrm{~cm}$} & 2 & 47.07 & 51.00 & 49.03 & 46.69 & 50.02 & 48.35 \\
\hline & 3 & 50.10 & 48.60 & 49.35 & 49.43 & 48.41 & 48.92 \\
\hline \multicolumn{2}{|c|}{ Average } & 48.58 & 49.80 & 49.19 & 48.06 & 49.22 & 48.64 \\
\hline \multirow{2}{*}{$\begin{array}{l}100 \\
\mathrm{~cm}\end{array}$} & 2 & 49.07 & 47.90 & 48.48 & 44.07 & 42.79 & 43.43 \\
\hline & 3 & 49.33 & 47.67 & 48.50 & 47.65 & 46.20 & 46.93 \\
\hline \multicolumn{2}{|c|}{ Average } & 49.20 & 47.78 & 48.49 & 45.86 & 44.50 & 45.18 \\
\hline \multirow{2}{*}{$\begin{array}{l}120 \\
\mathrm{~cm}\end{array}$} & 2 & 45.17 & 43.87 & 44.52 & 45.42 & 44.51 & 44.97 \\
\hline & 3 & 46.27 & 47.90 & 47.08 & 41.74 & 46.47 & 44.11 \\
\hline \multicolumn{2}{|c|}{ Average } & 45.72 & 45.88 & 45.80 & 43.58 & 45.49 & 44.54 \\
\hline \multirow{2}{*}{$B \times C$} & 2 & 47.10 & 47.59 & 47.34 & 45.39 & 45.77 & 45.58 \\
\hline & 3 & 48.57 & 48.06 & 48.31 & 46.27 & 47.03 & 46.65 \\
\hline \multicolumn{2}{|c|}{ Mean } & 47.83 & 47.82 & & 45.83 & 46.40 & \\
\hline \multicolumn{8}{|c|}{ LSD at 0.05 level for } \\
\hline \multicolumn{4}{|c|}{ Row spacing $(A)$} & 2.04 & & & 1.79 \\
\hline \multicolumn{4}{|c|}{ Ploughing number (B) } & 0.42 & & & 0.51 \\
\hline \multicolumn{4}{|c|}{ Cane variety (C) } & N.S & & & 0.51 \\
\hline \multicolumn{4}{|l|}{$A \times B$} & 0.72 & & & 0.89 \\
\hline \multicolumn{4}{|l|}{$A \times C$} & 0.72 & & & 0.89 \\
\hline \multirow{2}{*}{\multicolumn{4}{|c|}{$\mathrm{B} \times \mathrm{C}$}} & 0.59 & & & N.S \\
\hline & \multicolumn{3}{|c|}{$A \times B \times C$} & 1.02 & & & 1.26 \\
\hline
\end{tabular}




\section{Millable stalk height:}

Results in Table 2 revealed that increasing row spacing from 80 to 100 and $120 \mathrm{~cm}$ led to a significant decrease in millable stalk height. The tallest stalks of sugarcane, grown either as plant or $1^{\text {st }}$ ratoon, resulted from planting it in rows of 80$\mathrm{cm}$ apart, in the $1^{\text {st }}$ and $2^{\text {nd }}$ seasons. These results are in accordance with those obtained by El-Shafai and Ismail (2006) and Ahmed and Khaled (2008) who came up with the same findings.

The results revealed that millable stalk height was significantly affected by ploughing number in both seasons. Results showed that ploughing three passes increases millable stalk height compared with ploughing in two passes. El-Sayed (2000) and Osman, et al. (2004) showed that millable stalk height was significantly affected by ploughing passes numbers.

Data in the same table clear that the tested sugarcane varieties differed significantly in millable stalk height in both seasons. Sugarcane G.95-21 variety appeared the superiority over G.95-19 variety in this trait. These results may be due to genetic differences among cane varieties. Similar results were given by Sundara (2003) and Taha, et al. (2008).

Moreover, the data showed that millable stalk height responded significantly to the interactions among studied factors, except that between ploughing passes number and varieties, in both seasons. The tallest millable stalk were obtained from G.95-21 variety planted after three ploughing passes in rows spaced at $80-\mathrm{cm}$ apart.

Table 2. Millable stalk height $(\mathrm{cm})$ of the tested sugarcane varieties as affected by row spacing and number of ploughing passes

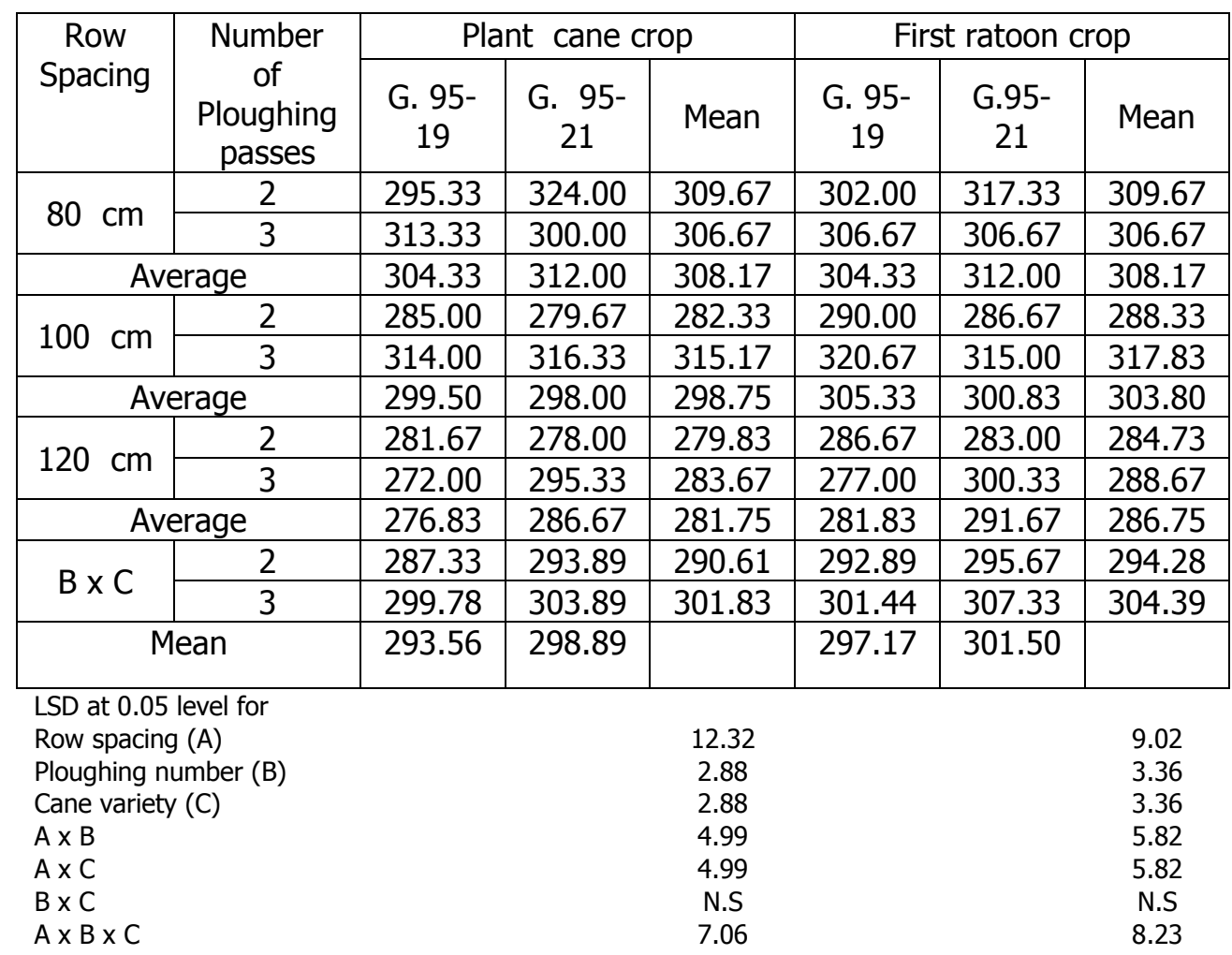




\section{Millable stalk diameter:}

Results in Table 3 showed that millable cane diameter was significantly affected by the inter-row spacing in the $2^{\text {nd }}$ season only. However, it was observed that planting sugarcane in the widest inter-row spacing $(120 \mathrm{~cm})$ resulted in the thicker millable stalk compared with the narrower ones (80 or 100 $\mathrm{cm}$ ). This result may be attributed to the great competition among plants in dense planting in case of narrow spacing on growth factors, i.e. nutrients and solar radiation, in addition to the negative influence of mutual shading. Similar results were reported by Shah-Nawaz, et al. (2000) and El-Geddawy, et al. (2002), who reported that the wider row spacing $(140 \mathrm{~cm})$ significantly recorded higher values of thicker stalks, compared with those of narrower spacing of $100 \mathrm{~cm}$.

Also, the results showed that ploughing soil surface in two passes resulted in thicker cane stalks compared to that ploughed in three passes. This effect was significant in the $2^{\text {nd }}$ season only. These results are in agreement with those obtained by El-Sayed (2000) and Osman, et al. (2004) who reported that number of ploughing attained a significant difference in stalk diameter as affected by ploughing passes number. The increase in millable cane diameter accompanied the reduction in ploughing number could be due to that increasing ploughing passes number directed plant potential to increasing its stalk height on the account of stalk diameter.

The tested sugarcane varieties differed significantly in millable stalk diameter. In both seasons, the thickset diameter was obtained by G. 95-21 variety. This result may be due to that G.95-21 variety had more growth vigour. El-Geddawy, et al. (2002) and El-Shafai and Ismail (2006) observed differences in stalk diameter among the tested varieties.

The results showed that stalk diameter was significantly affected by the possible interactions among the studied factors. 
Table 3. Millable stalk diameter $(\mathrm{cm})$ of the tested sugarcane varieties as affected by row spacing and number of ploughing passes

\begin{tabular}{|c|c|c|c|c|c|c|c|}
\hline \multirow{2}{*}{$\begin{array}{c}\text { Row } \\
\text { Spacing }\end{array}$} & \multirow{2}{*}{$\begin{array}{c}\text { Number } \\
\text { of } \\
\text { Ploughing } \\
\text { passes }\end{array}$} & \multicolumn{3}{|c|}{ Plant cane crop } & \multicolumn{3}{|c|}{ First ratoon crop } \\
\hline & & $\begin{array}{c}\text { G. 95- } \\
19\end{array}$ & $\begin{array}{c}\text { G. } \\
95-21\end{array}$ & Mean & $\begin{array}{c}\text { G. 95- } \\
19\end{array}$ & $\begin{array}{c}\text { G.95- } \\
21\end{array}$ & Mean \\
\hline \multirow{2}{*}{$80 \mathrm{~cm}$} & 2 & 2.77 & 2.85 & 2.81 & 2.84 & 2.92 & 2.88 \\
\hline & 3 & 2.37 & 2.58 & 2.48 & 2.42 & 2.63 & 2.53 \\
\hline \multicolumn{2}{|c|}{ Average } & 2.57 & 2.72 & 2.64 & 2.63 & 2.78 & 2.70 \\
\hline \multirow{2}{*}{$100 \mathrm{~cm}$} & 2 & 2.58 & 2.69 & 2.64 & 2.65 & 2.76 & 2.70 \\
\hline & 3 & 2.80 & 2.68 & 2.74 & 2.87 & 2.75 & 2.81 \\
\hline \multicolumn{2}{|c|}{ Average } & 2.69 & 2.69 & 2.69 & 2.76 & 2.76 & 2.76 \\
\hline \multirow{2}{*}{$120 \mathrm{~cm}$} & 2 & 2.76 & 2.51 & 2.63 & 2.81 & 2.56 & 2.68 \\
\hline & 3 & 2.74 & 2.84 & 2.798 & 2.79 & 2.90 & 2.85 \\
\hline \multicolumn{2}{|c|}{ Average } & 2.75 & 2.68 & 2.71 & 2.80 & 2.73 & 2.77 \\
\hline \multirow{2}{*}{$B \times C$} & 2 & 2.70 & 2.69 & 2.69 & 2.76 & 2.75 & 2.75 \\
\hline & 3 & 2.64 & 2.70 & 2.67 & 2.69 & 2.76 & 2.73 \\
\hline \multicolumn{2}{|c|}{ Mean } & 2.67 & 2.69 & & 2.73 & 2.75 & \\
\hline \multicolumn{8}{|c|}{ LSD at 0.05 level for } \\
\hline \multicolumn{4}{|c|}{ Row spacing (A) } & N.S & & & 0.05 \\
\hline \multicolumn{4}{|c|}{ Ploughing number (B) } & N.S & & & 0.01 \\
\hline \multicolumn{4}{|c|}{ Cane variety (C) } & 0.01 & & & 0.01 \\
\hline \multicolumn{4}{|l|}{$A \times B$} & 0.05 & & & 0.02 \\
\hline \multicolumn{4}{|l|}{$A \times C$} & 0.05 & & & 0.02 \\
\hline \multicolumn{4}{|l|}{$B \times C$} & 0.04 & & & 0.02 \\
\hline \multicolumn{4}{|l|}{$A \times B \times C$} & 0.06 & & & 0.03 \\
\hline
\end{tabular}

\section{Total soluble solids percentage in juice (brix percentage)}

Results in Table 4 pointed out that total soluble solids (TSS\%) was significantly influenced by row spacing treatments in the $2^{\text {nd }}$ season. These results are in agreement with those reported by El-Sayed (2000) and Ahmed and Khaled (2008) who reported that that brix \% was significantly affected by row spacing treatments.

Significant difference in brix \% as affected by number of ploughing passes was found in the $2^{\text {nd }}$ season. This result is in harmony with that obtained by El-Sayed (2000) and Osman, et al. (2004), who noted that number of ploughing passes had a significant difference in brix \%.

Furthermore, results in the same table reveled that the examined sugar cane varieties varied significantly in TSS $\%$ in the plant cane and $1^{\text {st }}$ ratoon crops. Sugarcane G.95-21 variety recorded the highest brix \% in both seasons. Difference between the two varieties could be due to their genetic structure. which could be due to their genetic structure.. These results are in line with those obtained by Ahmed, et al. (2005) and Taha, et al. (2008) who found that exhibited statistical differences in Brix \% among the studied cane varieties.

Brix $\%$ was significantly affected by the interaction among the three studied factors in the $2^{\text {nd }}$ season. 
Table 4. Brix percentage (T.S.S \%) of the tested sugarcane varieties as affected by row spacing and number of ploughing passes

\begin{tabular}{|c|c|c|c|c|c|c|c|}
\hline \multirow{2}{*}{$\begin{array}{c}\text { Row } \\
\text { Spacing }\end{array}$} & $\begin{array}{c}\text { Number of } \\
\text { Ploughing } \\
\text { passes }\end{array}$ & \multicolumn{3}{|c|}{ Plant cane crop } & \multicolumn{3}{c|}{ First ratoon crop } \\
\cline { 3 - 9 } & G. 95- & G. 95- & Mean & G. 95- & G.95-21 & Mean \\
\hline \multirow{2}{*}{$80 \mathrm{~cm}$} & 2 & 21.13 & 21.40 & 21.27 & 21.63 & 21.90 & 21.77 \\
\cline { 2 - 9 } & 3 & 20.33 & 20.53 & 20.43 & 20.83 & 21.03 & 20.93 \\
\hline \multicolumn{2}{|c|}{ Average } & 20.73 & 20.97 & 20.85 & 21.23 & 21.47 & 21.53 \\
\hline \multirow{2}{*}{$100 \mathrm{~cm}$} & 2 & 20.07 & 20.37 & 20.22 & 20.23 & 20.53 & 20.38 \\
\cline { 2 - 9 } & 3 & 21.30 & 21.70 & 21.50 & 21.80 & 22.20 & 22.00 \\
\hline \multicolumn{2}{|c|}{ Average } & 20.68 & 21.03 & 20.86 & 21.02 & 21.37 & 21.19 \\
\hline \multirow{2}{*}{$120 \mathrm{~cm}$} & 2 & 20.53 & 20.83 & 20.68 & 21.03 & 21.33 & 21.18 \\
\cline { 3 - 9 } & 3 & 20.23 & 20.27 & 20.25 & 20.73 & 20.43 & 20.58 \\
\hline \multicolumn{2}{|c|}{ Average } & 20.38 & 20.55 & 20.47 & 20.88 & 20.88 & 20.88 \\
\hline \multirow{2}{*}{ B X C } & 2 & 20.58 & 20.87 & 20.72 & 20.97 & 21.26 & 21.11 \\
\cline { 2 - 9 } & 3 & 20.62 & 20.83 & 20.73 & 21.12 & 21.22 & 21.17 \\
\hline \multicolumn{2}{|c|}{ Mean } & 20.60 & 20.85 & & 21.04 & 21.24 & \\
\hline
\end{tabular}

LSD at 0.05 level for

Row spacing (A)

Ploughing number (B)

N.S

0.03

Cane variety (C)

N.S

0.02

$A \times B$

0.15

0.02

$A \times C$

0.20

0.03

$B \times C$

N.S

0.03

$A \times B \times C$

N.S

0.03

N.S

0.04

\section{Sucrose percentage:}

Data in Table 5 reveal that sucrose percentage was significantly influenced by the inter-row spacing in the $1^{\text {st }}$ ratoon crop. This finding is in agreement with that obtained by Sundara (2003) and Osman, et al. (2004), who reported that the studied row spacing had a significant difference in sucrose $\%$.

Results in the same table showed no statistical difference in sucrose \% due to the studied number of ploughing passes in the two seasons. Moreover, the tested cane varieties were not significantly different in sucrose $\%$ in both seasons. Similar results were reported by kanwar, et al. (1988), who found that cane varieties did not show any differences in quality parameters.

Sucrose percentage was significantly affected by the interactions between number of ploughing passes and sugarcane varieties in the first ratoon crop. The highest sucrose \% was recorded by G.95-19 grown in soil ploughed three passes. The $2^{\text {nd }}$ order interaction had a significant effect on this trait in the $1^{\text {st }}$ ratoon crop. The maximum sucrose \% was obtained from G.95-19 variety planted in soil ploughed three passes in rows spaced at $100-\mathrm{cm}$ apart. 
Table 5: Sucrose percentage of the tested sugarcane varieties as affected by row spacing and number of ploughing passes

\begin{tabular}{|c|c|c|c|c|c|c|c|}
\hline \multirow{2}{*}{$\begin{array}{c}\text { Row } \\
\text { Spacing }\end{array}$} & \multirow{2}{*}{$\begin{array}{c}\text { Number } \\
\text { of } \\
\text { Ploughing } \\
\text { passes }\end{array}$} & \multicolumn{3}{|c|}{ Plant cane crop } & \multicolumn{3}{|c|}{ First ratoon crop } \\
\hline & & $\begin{array}{c}\text { G. 95- } \\
19\end{array}$ & $\begin{array}{c}\text { G. 95- } \\
21\end{array}$ & Mean & $\begin{array}{c}\text { G. 95- } \\
19\end{array}$ & $\begin{array}{c}\text { G.95- } \\
21\end{array}$ & Mean \\
\hline \multirow{2}{*}{$80 \mathrm{~cm}$} & 2 & 17.67 & 18.00 & 17.83 & 18.67 & 18.90 & 18.78 \\
\hline & 3 & 17.00 & 17.00 & 17.00 & 17.90 & 17.93 & 17.92 \\
\hline \multicolumn{2}{|c|}{ Average } & 17.33 & 17.50 & 17.42 & 18.28 & 18.42 & 18.35 \\
\hline \multirow{2}{*}{$100 \mathrm{~cm}$} & 2 & 16.67 & 16.67 & 16.67 & 16.97 & 17.07 & 17.02 \\
\hline & 3 & 18.00 & 18.33 & 18.17 & 19.07 & 19.00 & 19.03 \\
\hline \multicolumn{2}{|c|}{ Average } & 17.33 & 17.50 & 17.42 & 18.02 & 18.03 & 18.03 \\
\hline \multirow{2}{*}{$120 \mathrm{~cm}$} & 2 & 17.00 & 17.33 & 17.17 & 17.97 & 18.37 & 18.17 \\
\hline & 3 & 17.00 & 16.67 & 16.83 & 17.90 & 16.73 & 17.32 \\
\hline \multicolumn{2}{|c|}{ Average } & 17.00 & 17.00 & 17.00 & 17.93 & 17.55 & 17.74 \\
\hline \multirow{2}{*}{$B \times C$} & 2 & 17.11 & 17.33 & 17.22 & 17.87 & 18.11 & 17.99 \\
\hline & 3 & 17.33 & 17.33 & 17.33 & 18.29 & 17.89 & 18.09 \\
\hline \multicolumn{2}{|c|}{ ean } & 17.22 & 17.33 & & 18.08 & 18.00 & \\
\hline
\end{tabular}

LSD at 0.05 level for

$\begin{array}{lcr}\text { Row spacing (A) } & \text { N.S } & 0.37 \\ \text { Ploughing number (B) } & \text { N.S } & \text { N.S } \\ \text { Cane variety (C) } & \text { N.S } & \text { N.S } \\ \text { A } \times \text { B } & 0.42 & 0.37 \\ \text { A } \text { C } & \text { N.S } & \text { N.S } \\ \text { B } \times \text { C } & \text { N.S } & 0.30 \\ \text { A } \times \text { B } \times \text { C } & \text { N.S } & 0.53\end{array}$

\section{Sugar recovery percentage:}

Data in Table 6 showed that sugar recovery percentage was significantly influenced by the inter-row spacing in the $1^{\text {st }}$ ratoon crop. Planting sugarcane at $100-$ $\mathrm{cm}$ width gave the highest values of this trait compared with the other inter-row spacing. This result was in line with that reported by Sundara (2003) and Osman, et al. (2004), who reported that the row spacing attained a significant influence on the sugar recovery percentage.

The results cleared that sugar recovery \% was insignificantly affected by number of ploughing passes in the $1^{\text {st }}$ and $2^{\text {nd }}$ seasons. This result coincides with those mentioned by Ahmed, et al. (2005), who found insignificant differences in sugar recovery $\%$ as affected by ploughing number. Meantime, the difference between the two sugarcane varieties was insignificant, in both crops. This result is in line with that 
obtained by Kanwar, et al. (1988), who found that cane varieties did not show any differences in quality parameters.

Sugar recovery $\%$ was significantly affected by the interaction between interrow spacing and number of ploughing in both plant cane and first ratoon crops. Moreover, this trait was significantly affected by the second order interaction among the three studied factors, in the $1^{\text {st }}$ ratoon. The highest mean value of sugar recovery $\%$ was obtained by growing G.95-19 sugarcane variety in soil ploughed three passes in rows spaced at 100-cm apart.

Table 6. Sugar recovery percentage of the tested sugarcane varieties as affected by

\begin{tabular}{|c|c|c|c|c|c|c|c|}
\hline \multirow{2}{*}{$\begin{array}{c}\text { Row } \\
\text { Spacing }\end{array}$} & \multirow{2}{*}{$\begin{array}{c}\text { Number of } \\
\text { Ploughing } \\
\text { passes }\end{array}$} & \multicolumn{3}{|c|}{ Plant cane crop } & \multicolumn{3}{|c|}{ First ratoon crop } \\
\hline & & $\begin{array}{c}\text { G. } 95- \\
19 \\
\end{array}$ & $\begin{array}{c}\text { G. } 95- \\
21 \\
\end{array}$ & Mean & $\begin{array}{c}\text { G. } 95- \\
19 \\
\end{array}$ & G.95-21 & Mean \\
\hline \multirow{2}{*}{$80 \mathrm{~cm}$} & 2 & 12.83 & 13.07 & 12.95 & 12.93 & 13.67 & 13.30 \\
\hline & 3 & 12.20 & 12.23 & 12.22 & 12.93 & 12.23 & 12.58 \\
\hline \multicolumn{2}{|c|}{ Average } & 12.52 & 12.65 & 12.58 & 12.93 & 13.95 & 12.94 \\
\hline \multirow{2}{*}{$100 \mathrm{~cm}$} & 2 & 12.60 & 11.93 & 12.27 & 14.00 & 12.30 & 13.15 \\
\hline & 3 & 13.20 & 13.23 & 13.22 & 13.90 & 14.07 & 13.98 \\
\hline \multicolumn{2}{|c|}{ Average } & 12.90 & 12.58 & 12.74 & 13.95 & 13.18 & 13.57 \\
\hline \multirow{2}{*}{$120 \mathrm{~cm}$} & 2 & 12.20 & 12.57 & 12.38 & 12.73 & 12.97 & 12.85 \\
\hline & 3 & 12.13 & 11.83 & 11.98 & 12.40 & 12.90 & 12.65 \\
\hline \multicolumn{2}{|c|}{ Average } & 12.17 & 12.20 & 12.18 & 12.57 & 12.93 & 12.75 \\
\hline \multirow{2}{*}{$B \times C$} & 2 & 12.54 & 12.52 & 12.53 & 13.22 & 12.98 & 13.10 \\
\hline & 3 & 12.51 & 12.43 & 12.47 & 13.08 & 13.07 & 13.07 \\
\hline \multicolumn{2}{|c|}{ Mean } & 12.53 & 12.48 & & 13.15 & 13.02 & \\
\hline \multicolumn{8}{|c|}{ LSD at 0.05 level for } \\
\hline \multicolumn{2}{|c|}{ Row spacing $(A)$} & \multicolumn{5}{|c|}{ N.S } & 0.62 \\
\hline \multicolumn{2}{|c|}{ Ploughing number (B) } & \multicolumn{5}{|c|}{ N.S } & N.S \\
\hline \multicolumn{2}{|c|}{ Cane variety (C) } & \multicolumn{5}{|c|}{ N.S } & N.S \\
\hline \multirow{2}{*}{\multicolumn{2}{|c|}{$A \times B$}} & \multicolumn{5}{|c|}{0.65} & 0.85 \\
\hline \multirow{2}{*}{\multicolumn{2}{|c|}{$\begin{array}{l}A \times C \\
B \times C\end{array}$}} & \multicolumn{5}{|c|}{ N.S } & N.S \\
\hline & & \multicolumn{5}{|c|}{ N.S } & N.S \\
\hline \multicolumn{2}{|l|}{$\begin{array}{l}B \times C \\
A \times B \times C\end{array}$} & & & N.S & & & 1.20 \\
\hline
\end{tabular}

\section{Cane yield:}

Data in Table 7 pointed to a significant effect on cane yield due to the studied inter-row spacings in both plant and $1^{\text {st }}$ ratoon crops. Increasing inter-row spacing from 80 to 100 and $120 \mathrm{~cm}$ led to a gradual decrease in cane yield in both cane crops. These results may be due to the fact that the narrower the inter-row spacing the higher the millable stalk number/fed and stalk height (Tables 1 and 2). Similar results 
were obtained by Shah-Nawaz, et al. (2000), Gowda, et al. (2001), El-Geddawy, et al. (2002) and El-Shafai and Ismail (2006), who found that planting sugarcane in rows spaced at $80-\mathrm{cm}$ apart attained significant increases in cane yields/fed compared with 100 and $120 \mathrm{~cm}$.

Data in the same table showed that plougings number had a significant influence on cane yield. Ploughing soil before planting three passes resulted in producing 0.94 and 1.01 tons of canes higher/fed than that ploughed in two passes, in the plant cane and first ratoon, respectively. These results may be due to higher millable stalk number/fed and cane height (Tables 1 and 2) recorded in case of preparing seed bed by ploughing soil in three passes compared to that ploughed in two passes, which may be due to the positive influence on germination, emergence and growth of cane plants. These results are in agreement with those obtained by ElSayed (2000) and Ahmed, et al. (2005), who found that plouging number had a significant effect on cane yield.

Results showed a significant difference in cane yield between the two sugarcane varieties in first ratoon crop only. The variety G. 95-21surpassed G. 95-19 by, 0.49 ton /fed in the $2^{\text {nd }}$ season. These results could be attributed to higher values of millble stalk number, height and diameter (Tables 1,2 and 3) recorded by the $1^{\text {st }}$ one. The effective role of varieties on cane yield was also reported by Gowda, et al. (2001), Sundara (2003) and Ahmed and Khaled (2008), who found that sugarcane varieties differed significantly in cane yields.

The results revealed that cane yield was significantly affected by the interactions between the studied factors in both crops, except that of ploughing number $x$ cane varieties in the plant cane crop. The highest cane yield was obtained by planting sugarcane G.95-21 variety in rows of $80-\mathrm{cm}$ apart after ploughing three passes. 
Table 7. Net cane yield (tons/fed) of the tested sugarcane varieties as affected by row spacing and number of ploughing passes

\begin{tabular}{|c|c|c|c|c|c|c|c|}
\hline \multirow{2}{*}{$\begin{array}{c}\text { Row } \\
\text { Spacing }\end{array}$} & \multirow{2}{*}{$\begin{array}{c}\text { Number of } \\
\text { Ploughing } \\
\text { passes }\end{array}$} & \multicolumn{3}{|c|}{ Plant cane crop } & \multicolumn{3}{|c|}{ First ratoon crop } \\
\hline & & $\begin{array}{c}\text { G. } 95- \\
19 \\
\end{array}$ & $\begin{array}{c}\text { G. } 95- \\
21 \\
\end{array}$ & Mean & $\begin{array}{c}\text { G. } 95- \\
19 \\
\end{array}$ & $\begin{array}{c}\text { G.95- } \\
21 \\
\end{array}$ & Mean \\
\hline \multirow{2}{*}{$80 \mathrm{~cm}$} & 2 & 48.00 & 53.00 & 50.50 & 48.83 & 50.90 & 49.87 \\
\hline & 3 & 51.00 & 49.33 & 50.17 & 50.63 & 50.17 & 50.40 \\
\hline \multicolumn{2}{|c|}{ Average } & 49.50 & 51.17 & 50.33 & 49.73 & 50.53 & 50.13 \\
\hline \multirow{2}{*}{$100 \mathrm{~cm}$} & 2 & 50.00 & 49.33 & 49.67 & 46.53 & 44.87 & 45.70 \\
\hline & 3 & 51.33 & 49.67 & 50.50 & 50.07 & 48.07 & 49.07 \\
\hline \multicolumn{2}{|c|}{ Average } & 50.67 & 49.50 & 50.08 & 48.30 & 46.47 & 47.38 \\
\hline \multirow{2}{*}{$120 \mathrm{~cm}$} & 2 & 47.67 & 44.67 & 46.17 & 47.53 & 46.93 & 47.23 \\
\hline & 3 & 47.33 & 49.67 & 48.50 & 43.57 & 49.17 & 46.37 \\
\hline \multicolumn{2}{|c|}{ Average } & 47.50 & 47.17 & 47.33 & 45.55 & 48.05 & 46.80 \\
\hline \multirow{2}{*}{$B \times C$} & 2 & 48.56 & 49.00 & 48.78 & 47.63 & 47.57 & 47.60 \\
\hline & 3 & 49.89 & 49.56 & 49.72 & 48.09 & 49.13 & 48.61 \\
\hline \multicolumn{2}{|c|}{ Mean } & 48.89 & 49.28 & & 47.86 & 48.35 & \\
\hline
\end{tabular}

LSD at 0.05 level for

$\begin{array}{lcr}\text { Row spacing (A) } & 2.15 & 1.40 \\ \text { Ploughing number (B) } & 0.30 & 0.50 \\ \text { Cane variety (C) } & \text { N.S } & 0.50 \\ \text { A x B } & 0.80 & 0.87 \\ \text { A X C } & 0.80 & 0.87 \\ \text { B X C } & \text { N.S } & 0.71 \\ \text { A x B x C } & 1.13 & 1.23\end{array}$

\section{Sugar yield:}

Data in Table 8 show that sugar yield was significantly affected by inter-row spacing in both of the plant cane and $1^{\text {st }}$ ratoon crops, without significant variance between 80 and $100-\mathrm{cm}$ rows. These results may be due to higher cane yield produced under narrower spacings (Table 7). These results are in line with those reported by El-Sayed (2000), Gowda, et al. (2001) and El-Shafai and Ismail (2006), who found that planting sugarcane in rows spaced at $80-\mathrm{cm}$ apart attained significant increases in sugar yield/fed compared with that gained by planting it in rows spaced at 100 and $120 \mathrm{~cm}$.

The results showed insignificant effect on sugar yield due to the number of ploughing passes in the $1^{\text {st }}$ and $2^{\text {nd }}$ seasons. Likewise, the difference between the tested varieties in sugar yield was not enough to reach the level of significance in both seasons.

Results in Table 8 cleared that sugar yield was significantly affected by the possible interactions of the studied factors in both seasons, except the interaction between the number of ploughing and varieties. The highest sugar yields were 
obtained from G.95-21 variety grown in rows of $80-\mathrm{cm}$ apart after ploughing soil three passes.

Table 8. Sugar yield (tons/fed) of the tested sugarcane varieties as affected by row

\begin{tabular}{|c|c|c|c|c|c|c|c|}
\hline \multirow{2}{*}{$\begin{array}{c}\text { Row } \\
\text { Spacing }\end{array}$} & \multirow{2}{*}{$\begin{array}{c}\text { Number of } \\
\text { Ploughing } \\
\text { passes }\end{array}$} & \multicolumn{3}{|c|}{ Plant cane crop } & \multicolumn{3}{|c|}{ First ratoon crop } \\
\hline & & $\begin{array}{c}\text { G. } 95- \\
19 \\
\end{array}$ & $\begin{array}{c}\text { G. } 95- \\
21 \\
\end{array}$ & Mean & $\begin{array}{c}\text { G. } 95- \\
19 \\
\end{array}$ & G.95-21 & Mean \\
\hline \multirow{2}{*}{$80 \mathrm{~cm}$} & 2 & 6.16 & 6.93 & 6.55 & 6.32 & 6.95 & 6.63 \\
\hline & 3 & 6.23 & 6.04 & 6.13 & 6.55 & 6.14 & 6.35 \\
\hline \multicolumn{2}{|c|}{ Average } & 6.19 & 6.49 & 6.34 & 6.43 & 6.54 & 6.49 \\
\hline \multirow{2}{*}{$100 \mathrm{~cm}$} & 2 & 6.30 & 5.88 & 6.09 & 6.51 & 5.52 & 6.02 \\
\hline & 3 & 6.78 & 6.57 & 6.68 & 6.96 & 6.76 & 6.86 \\
\hline \multicolumn{2}{|c|}{ Average } & 6.54 & 6.23 & 6.38 & 6.74 & 6.14 & 6.44 \\
\hline \multirow{2}{*}{$120 \mathrm{~cm}$} & 2 & 5.81 & 5.60 & 5.71 & 6.05 & 6.09 & 6.07 \\
\hline & 3 & 5.73 & 5.87 & 5.80 & 5.40 & 6.34 & 5.87 \\
\hline \multicolumn{2}{|c|}{ Average } & 5.77 & 5.74 & 5.75 & 5.73 & 6.21 & 5.97 \\
\hline \multirow{2}{*}{$B \times C$} & 2 & 6.09 & 6.14 & 6.11 & 6.29 & 6.18 & 6.24 \\
\hline & 3 & 6.25 & 6.16 & 6.20 & 6.31 & 6.41 & 6.36 \\
\hline \multicolumn{2}{|c|}{ Mean } & 6.17 & 6.15 & & 6.30 & 6.30 & \\
\hline
\end{tabular}

LSD at 0.05 level for

Row spacing $(A)$

Ploughing number (B)

Cane variety $(C)$

$A \times B$

$A \times C$

$B \times C$

$A \times B \times C$

$\begin{array}{lc}0.33 & 0.38 \\ \text { N.S } & \text { N.S } \\ \text { N.S } & \text { N.S } \\ 0.32 & 0.42 \\ 0.32 & 0.42 \\ \text { N.S } & \text { N.S } \\ 0.45 & 0.60\end{array}$

\section{REFERENCES}

1. Ahmed, A.M., R.A. Abo El-Ghait, A.M.H. Osman and G.S. El-Sayed. 2005. Response of three sugar cane varieties to number of plougings and nitrogen application. J. Agric. Sci., Mansoura Univ., 30 (1): 1-21.

2. Ahmed A.Z. and K.A.M. Khaled. 2008. Marker assisted selection for yield and some quality traits of sugarcane genotypes under different row spacing. Minia J. Agric. Res. \& Develop., 28 (4): 585-606.

3. Association of Official Agricultural Chemist. 1995. Official methods of analysis published by the A.O.A.C., Box 540, Washington. 
4. El-Geddawy, I.H., D.G. Darweish, A.A. El-Sherbiny and E.E.A. El-Hady. 2002. Effect of row spacing and number of buds/seed setts on: 3. Yield components of ratoon crops for some sugar cane varieties ratoon. Pakistan Sugar J., 17 (2): 2-8.

5. El-Shafai, A.M.A. and A.M.A. Ismail. 2006. Effect of row spacing on yield and quality of some promising sugarcane varieties. Egypt J. Appl. Sci., 21 (11): 32-46.

6. El-Sayed, G.S. 2000. Effect of some tillage practices and plant spacing on sugar cane productivity in Sohage. Ph.D. Thesis, Agron. Dept., Fac. Agric., Moshtohor, Zagazig Univ., Egypt.

7. Gowda, C.C., T.S. Vageesh and S. Panchaksharaiah. 2001. Spacing and fertilizer requirements of Co-7704, a promising sugarcane variety for Zone-7 of Karnataka. Mysore J. Agric. Sci., 35 (1): 64-71. Record 608 of 772 - CAB Absts., 2002/082003/10.

8. Kanwar, R.S., S. Sing, B.S. Bains, K. K. Sharma and A. I. S. Garch. 1988. Yield and quality of sugar cane ratoon crop as influenced by varieties, gap filling and nitrogen levels. Bharatiya Sugar, 14 (2): 81-83 (C.F. Sugar Cane Absts., 6: 18).

9. Osman, A.M.H., G. S. El-sayed A. I. Nafei. 2004. Effect of row spacing and plouging on yield and quality of some sugar cane varieties. Egypt J. Appl. Sci., 19 (2): 58-75.

10. Raskar, B.S. and P.G. Bhoi. 2003. Yield attributes of sugarcane as influenced by intra-row spacings, fertilizer levels and planting materials. Indian Sugar, 53 (5): 327-331.

11. Shah-Nawaz, V., A. Riaz, Abdul-Jabbar, M. Tariq and A. Ashfaq. 2000. Biological traits of autumn sugarcane as influenced by spatial arrangement and plantation method. Pakistan Sugar J., 15 (5): 15-19.

12. Snedecor, G.W. and W.G. Cochran. 1981. Statistical Methods. Oxfored and I.B.H. publishing G. $6^{\text {th }}$ Ed., 299-310.

13. Sundara, B. 2003. Response of new sugarcane varieties to wide row spacing. Proc. $65^{\text {th }}$ Ann. Convention Sugar Technol. Assoc. India, Bhubaneshwar, Orissa, India, 22-24, Aug., 2003: A 168-A 177. Record 768 of 772 - CAB Absts. 2003/112004/04.

14. Taha, E.M., Sh.A. Mokadem, A.Z. Ahmed and M.O. Galal. 2008. Assessment of the optimum seeding rate and nitrogen level for five sugarcane varieties. Minia J. Agric. Res. \& Develop., 28 (3): 469 -494 .

15. Yadav, R.L. and R.K. Sharma. 1980. Effect of nitrogen level and harvesting date on quality characteristics and yield of four sugar cane genotypes. Indian J. Agric. Sci., 50: 581-589. 


\section{تحديد المسافة المثلى بين الخطوط وعدد مرات الحرث لصنفي قصب سكر مبشرين}

أحمد زكى احمد ، عبد اللاهى محمد أحمد ، محمود سيد حسن عثمان

$$
\text { معه بحوث المحاصيل السكرية - مركز البحوث الزراعية - مصر }
$$

أجرى هذا البحث في مزرعة محطة البحوث الزر اعية بالمطاعنة بمحافظة الأقصر في

موسمي 2009/2008 و 2010 لتحديد المسافة المنلى بين الخطوط و أفضل عدد مرات

للحرث لإثثين من أصناف قصب السكر المبشرة. إثنتملت الدراسة على إثنى عشر معاملة مثلت

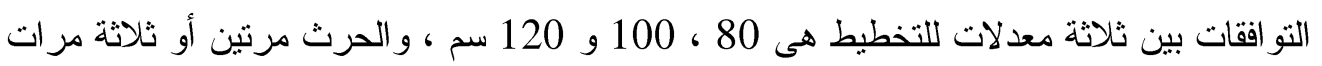

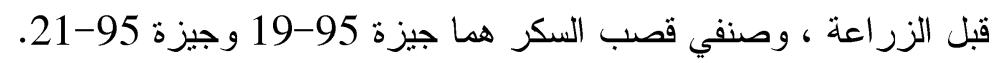

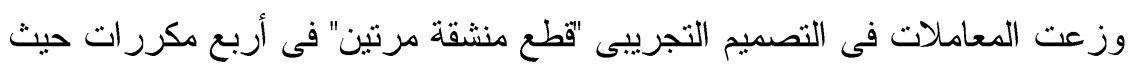

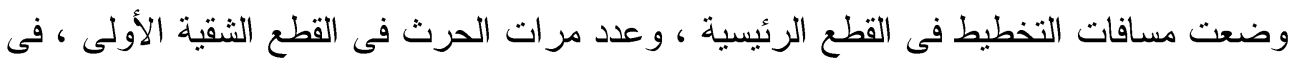
حين وزع الصنفان فى القطع الثقية الثانية .

أظهرت النتائج فروقاً معنوية يين مسافات التخطيط المدروسة علي عدد العيدان القابلة

للعصر/فدان وارتفاع وقطر العيدان و النسبة المئوية لكلٍ من المو اد الصلبة الذائبة الكلية (البركس)

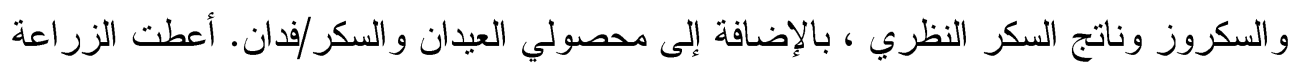

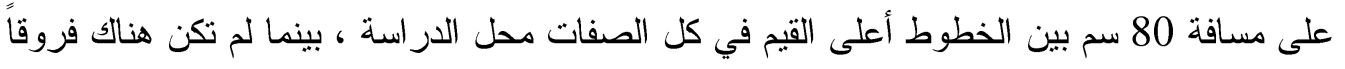

معنوية بين معدلي التخطبط 80 و 100 سم في عدد العيدان القابلة للعصر/فدان و ارتفاع العيدان

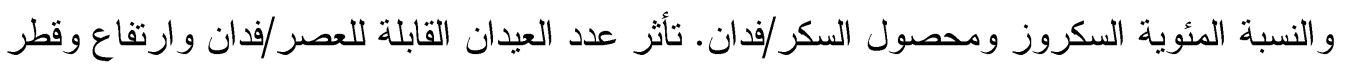

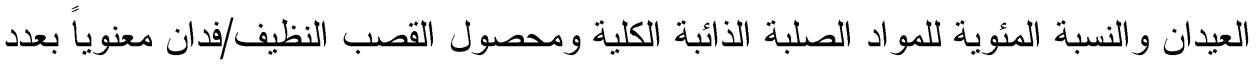

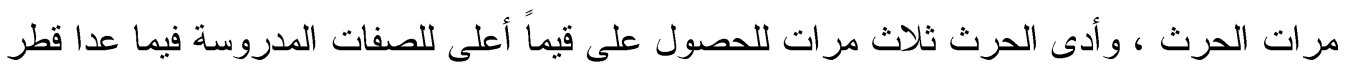

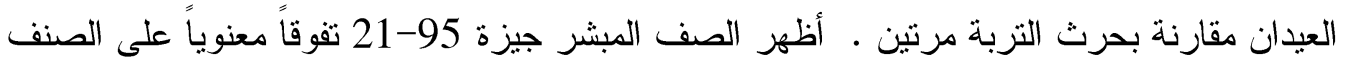
جيزة 95-19 في صفات عدد العيدان القابلة للعصر/فدان وارتفاع وقطر العيدان ، بالإضافة إلى لى لئل النسبة المئوية للمو اد الصلبة الذائبة الكلية ومحصول القصب النظيف النيف. تحت ظروف هذا البحث نوصى بزر اعة صنف القصب المبشر جيزة 95-21 في خطوط

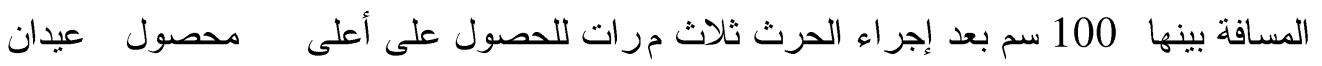
• مسكر/فدان 